Zeszyty Naukowe Szkoły Głównej Gospodarstwa Wiejskiego

Ekonomika i Organizacja Gospodarki Żywnościowej nr 117, 2017: 151-163

DOI 10.22630/EIOGZ.2017.117.11

\title{
Anetta Zielińska
}

Katedra Zarządzania

Uniwersytet Jana Kochanowskiego w Kielcach

Filia w Piotrkowie Trybunalskim

\section{Analiza porównawcza poziomu i struktury wydatków na działalność prewencyjną w zakresie bezpieczeństwa i higieny pracy ponoszonych przez przedsiębiorstwa przemysłu spożywczego w województwie łódzkim}

\section{Wstęp}

Wypadki przy pracy powodują znaczne straty w gospodarce [Lange 1990, ZUS 2009]. Według Siarneckiego [2001] dokładnie nikt nie policzył, jakie są koszty wypadków i może dlatego „bagatelizowane są straty, jakie ponosi pracodawca, gdy w wyniku wypadku w pracy szkodę ponosi pracownik i dochodzi do zniszczenia części majątku firmy". Zasadnicze znaczenie dla właściwego wyznaczenia kosztów wypadków obciążających przedsiębiorstwo ma prawidłowa identyfikacja składników kosztów, których suma tworzy całkowity koszt wypadku [Pawłowska i Rzepecki 1998].

Wskazana w tytule artykułu branża spożywcza, zajmująca się produkcją artykułów spożywczych i napojów, zaliczana jest do przetwórstwa przemysłowego. Zdaniem Urbana [2010] jest ona drugim, obok rolnictwa, głównym trzonem gospodarki żywnościowej.

Do badań wybrano województwo łódzkie, położone w centralnej części kraju, gdyż istnieje w nim duża koncentracja podmiotów o zróżnicowanym zakresie przetwórstwa artykułów spożywczych. Podejmowane przedsięwzięcia poprawiające warunki pracy są na ogół zasadne i powinny być wpisane w zakres rutynowych analiz. Istotne jest jednak poszukiwanie coraz lepszych rozwiązań pozwalających na ograniczenie wypadków przy pracy i ich kosztów [Maciołek i Zielińska 2012]. Na kształtowanie się liczby wypadków przy pracy, 


\section{2}

bezpośrednio i pośrednio wpływa między innymi świadomość społeczeństwa w zakresie zagrożeń, szkolenia dotyczące bezpiecznego wykonywania pracy [Rzepecki i Serafińska 2004] oraz poziom wiedzy pracowników w zakresie bezpieczeństwa i higieny pracy (BHP). Liczba wypadków przy pracy w przedsiębiorstwach związana jest $\mathrm{z}$ nakładami finansowymi ponoszonymi przez pracodawców na rzecz profilaktyki bezpieczeństwa i higieny pracy [Jakubowska 1978, Manteuffel 1979]. Badania lekarskie z uwzględnieniem czynników szkodliwych występujących na stanowisku pracy, właściwe kwalifikacje, doświadczenie oraz odpowiednie szkolenie pracowników w zakresie BHP powinny być ważniejszymi kryteriami sterowania bezpieczną pracą.

\section{Cel i metody badań}

W badaniach podjęto próbę rozpoznania różnic pomiędzy wydatkami ponoszonych na BHP a liczbą wypadków przy pracy w badanych przedsiębiorstwach.

Badania były prowadzone przez autorkę w latach 2012-2014. Objęto nimi duże przedsiębiorstwa przemysłu spożywczego działające na terenie województwa łódzkiego, które w okresie pięcioletnim, tj. w latach 2008-2012, nieprzerwanie prowadziły swoją działalność. Na podstawie danych GUS ustalono, że w województwie łódzkim, w przemyśle spożywczym według stanu na dzień 1 stycznia 2008 roku zarejestrowano'

- 2103 małych przedsiębiorstw zatrudniających do 9 pracowników;

- 723 średnie przedsiębiorstwa zatrudniające od 10 do 49 pracowników;

- 177 dużych przedsiębiorstw zatrudniających 50 i więcej pracowników.

Dla porównania, stan na dzień 1 stycznia 2013 roku był następujący:

- 1873 małych przedsiębiorstw zatrudniających do 9 pracowników;

- 644 średnie przedsiębiorstwa zatrudniające od 10 do 49 pracowników;

- 153 duże przedsiębiorstwa zatrudniające nie mniej niż 50 pracowników.

W wyborze obiektów badawczych zastosowano dobór celowy, będący najbardziej typowym przypadkiem doboru nielosowego. Polega on na subiektywnym doborze jednostek badanych do próby. Głównym kryterium doboru była wielkość przedsiębiorstwa oraz prowadzenie działalności gospodarczej na terenie województwa łódzkiego, w sektorze spożywczym.

Początkowym zamiarem było przeprowadzenie badań wyczerpujących [Klepacki 1984], gdyż do badań zakwalifikowano wstępnie wszystkie duże przedsiębiorstwa, czyli zatrudniające 50 i więcej pracowników, działające w sektorze

\footnotetext{
${ }^{1}$ Kryterium podziału przedsiębiorstw według GUS.
} 
spożywczym w sposób nieprzerwany przez okres pięć lat, tj. w latach 2008-2012. Część przedsiębiorstw jednak zaprzestała produkcji albo nastąpiły ich fuzje lub przejęcia. Ponadto z 36 przedsiębiorstw nie udało się uzyskać wiarygodnych danych. Jednak kompletne dane kwestionariusza ankiety udało się zgromadzić ze 116 przedsiębiorstw przemysłu spożywczego, które stanowiły $65,5 \%$ dużych przedsiębiorstw sektora przemysłu spożywczego województwa łódzkiego według stanu na dzień 1 stycznia 2008 roku. Ponadto prowadzona była dodatkowa weryfikacja zgromadzonych materiałów podczas rozmów z pracownikami służb BHP w badanych przedsiębiorstwach.

Do celów badawczych zastosowano podział według rodzaju prowadzonej przez przedsiębiorstwa działalności. W jego ramach wyodrębniono 6 branż:

1. Przetwarzanie i konserwowanie mięsa oraz produkcja wyrobów z mięsa badaniem objęto 56 przedsiębiorstw;

2. Produkcja wyrobów piekarskich i mącznych - 19 przedsiębiorstw;

3. Wytwarzanie wyrobów mleczarskich -10 spółdzielni;

4. Przetwarzanie i konserwowanie owoców i warzyw - 15 przedsiębiorstw;

5. Produkcja napojów -7 przedsiębiorstw;

6. Produkcja pozostałych artykułów spożywczych:

- przemiału zbóż oraz produkcji pasz - 1 przedsiębiorstwo;

- kakao, czekolady i wyrobów cukierniczych - 2 przedsiębiorstwa;

- kawy i konfekcjonowanie herbaty - 1 przedsiębiorstwo;

- ryb, skorupiaków i mięczaków - 1 przedsiębiorstwo;

- dań gotowych - 2 przedsiębiorstwa;

- pozostałych artykułów spożywczych, gdzie indziej niesklasyfikowanych -2 przedsiębiorstwa.

Przyjęte kryteria charakteryzują próbę badawczą z punktu widzenia bezpieczeństwa procesu gospodarczego w sektorze spożywczym. Wyniki otrzymane $\mathrm{w}$ toku prowadzonego procesu badawczego, dotyczące wydatków związanych z BHP $\mathrm{i}$ ich struktury zaprezentowano w formie metody opisowej, oraz za pomocą tabel i rysunków.

\section{Wyniki badań}

W pierwszym etapie badań określono poziom oraz kierunki zmian wydatków na działalność prewencyjną w przedsiębiorstwach przemysłu spożywczego w latach 2008-2012. Na rysunku 1 przedstawiono wielkość wydatków z tytułu działalności prewencyjnej w zakresie BHP w badanych przedsiębiorstwach. Widoczny jest wzrost tych wydatków (o 2,5\% między 2008 r. a 2012 r.), ale 


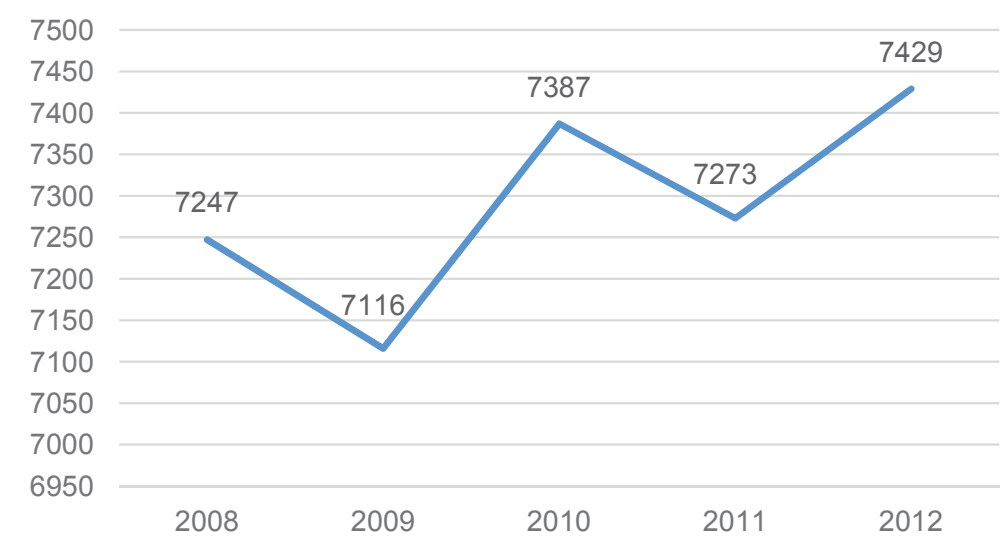

\section{Rysunek 1}

Wydatki ogółem na działalność prewencyjną w zakresie BHP w badanych przedsiębiorstwach sektora przemysłu spożywczego, w województwie łódzkim w latach 2008-2012 [tys. zł]

Źródło: Badanie własne.

niewielki w stosunku do przyrostu liczby wypadków przy pracy, który w tym samym okresie osiagnął ponad $29 \%$.

W badanej grupie przedsiębiorstw liczba wypadków przy pracy wzrosła z 258 w 2008 roku do 333 w 2012 roku, przy czym najmniej (211) zarejestrowano ich w 2009 roku, a najwięcej (358) w 2011 roku. Widoczna na rysunku 2 tendencja zwiększania się liczby wypadków przy pracy mogła być powiązana ze

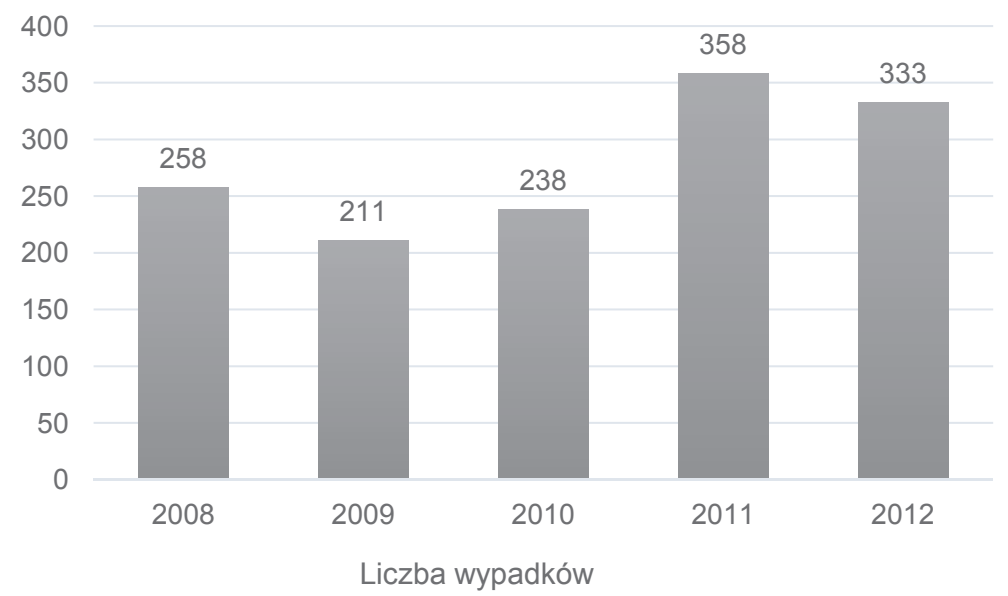

\section{Rysunek 2}

Liczba wypadków przy pracy ogółem, w badanych przedsiębiorstwach przemysłu spożywczego w województwie łódzkim w latach 2008-2012 Źródło: Badanie własne. 
zwiększaniem rozmiarów działalności prowadzonej przez badane przedsiębiorstwa.

Na podstawie zestawienia wydatków na działalność prewencyjną w zakresie BHP w układzie branżowym (tab. 1) można stwierdzić, że w dwóch branżach nastąpił spadek tych wydatków: w branży produkcji napojów - o 17,6\%, w branży produkcji wyrobów piekarskich i mącznych - o $36 \%$. W pozostałych branżach wydatki te wzrosły, przy czym najbardziej w branży wytwarzającej wyroby mleczarskie (o 38,7\%). W branży produkcji pozostałych artykułów spożywczych, branży mięsnej oraz owocowo-warzywnej przyrosty wydatków na działalność prewencyjną w zakresie BHP między 2008 rokiem a 2012 rokiem stanowiły odpowiednio $7,4,7$ i $2,1 \%$.

\section{Tabela 1}

Wydatki na BHP $w$ badanych przedsiębiorstwach przemysłu spożywczego według branż w województwie łódzkim w latach 2008-2012 [tys. zł]

\begin{tabular}{|l|c|c|c|c|c|}
\hline \multirow{2}{*}{ Branża } & \multicolumn{5}{|c|}{ Lata } \\
\cline { 2 - 6 } & 2008 & 2009 & 2010 & 2011 & 2012 \\
\hline $\begin{array}{l}\text { Przetwarzanie i konserwowanie mięsa } \\
\text { oraz produkcja wyrobów z mięsa }\end{array}$ & 3441 & 3485 & 3524 & 3527 & 3603 \\
\hline Produkcja wyrobów piekarskich i mącznych & 1122 & 624 & 632 & 665 & 718 \\
\hline Wytwarzanie wyrobów mleczarskich & 1258 & 1537 & 1742 & 1661 & 1745 \\
\hline $\begin{array}{l}\text { Przetwarzanie i konserwowanie owoców } \\
\text { i warzyw }\end{array}$ & 703 & 780 & 782 & 697 & 718 \\
\hline Produkcja napojów & 523 & 475 & 489 & 497 & 431 \\
\hline $\begin{array}{l}\text { Produkcja pozostałych artykułów spożywczych } \\
\text { (kakao, czekolady, kawy, ryb itd.) }\end{array}$ & 200 & 214 & 219 & 227 & 214 \\
\hline
\end{tabular}

Źródło: Badanie własne.

W tabeli 2 ukazano strukturę wydatków na działalność prewencyjną w zakresie BHP w badanych przedsiębiorstwach. Największy udział zajmowały na ogół wydatki związane z zakupem odzieży i obuwia roboczego pracowników. Następną, pod względem udziału, pozycję stanowiły wydatki na zakup środków czystości dla pracowników, których odsetek w badanym okresie oscylował między $19 \%$ w 2008 roku a 18\% w 2011 roku.

W przypadku wydatków na badania lekarskie pracowników w ostatnich latach badanego okresu zaobserwowano ustabilizowanie ich poziomu w stosunku do ogółu wydatków poniesionych na działalność profilaktyczną. Ich udział wahał się między 17,2\% w 2008 roku a 10,6\% w 2012 roku. Z kolei udział wydatków na zakup środków ochrony indywidualnej pracowników w całym okresie był ustabilizowany, stanowiąc od 12,6\% (2012 r.) do 13,5\% (2009 r.). Podobnie 
Tabela 2

Struktura wydatków na działalność prewencyjną w zakresie BHP w przedsiębiorstwach przemysłu spożywczego objętych badaniem w latach 2008-2012 [\%]

\begin{tabular}{|l|c|c|c|c|c|}
\hline \multirow{2}{*}{ Przeznaczenie wydatków } & \multicolumn{5}{|c|}{ Lata } \\
\cline { 2 - 6 } & 2008 & 2009 & 2010 & 2011 & 2012 \\
\hline Badania lekarskie pracowników & 17,2 & 11,2 & 10,9 & 11,3 & 10,6 \\
\hline $\begin{array}{l}\text { Zakup odzieży i obuwia roboczego } \\
\text { pracowników }\end{array}$ & 28,8 & 30,5 & 32,1 & 32,6 & 32,6 \\
\hline $\begin{array}{l}\text { Pomiar czynników szkodliwych dla zdrowia } \\
\text { na stanowiskach pracy }\end{array}$ & 1,1 & 1,2 & 1,1 & 1,2 & 1,6 \\
\hline Zakup środków czystości pracowników & 19,0 & 18,5 & 18,5 & 18,0 & 18,4 \\
\hline Szkolenia BHP pracowników & 2,8 & 4,0 & 3,3 & 3,5 & 4,1 \\
\hline $\begin{array}{l}\text { Zakup i instalacja środków ochrony zbiorowej } \\
\text { pracowników }\end{array}$ & 1,0 & 1,6 & 1,8 & 2,4 & 1,4 \\
\hline Utrzymanie szatni pracowniczej & 1,8 & 2,5 & 1,7 & 1,9 & 1,8 \\
\hline Zatrudnienie służb BHP & 10,3 & 11,4 & 11,5 & 11,2 & 11,8 \\
\hline $\begin{array}{l}\text { Zakup środków ochrony indywidualnej } \\
\text { pracowników }\end{array}$ & 12,8 & 13,5 & 13,4 & 12,4 & 12,6 \\
\hline Pozostałe & 5,3 & 5,6 & 5,8 & 5,4 & 5,2 \\
\hline Razem & 100,0 & 100,0 & 100,0 & 100,0 & 100,0 \\
\hline
\end{tabular}

Źródło: Badanie własne.

udział wydatków poniesionych na zatrudnienie służb BHP był stosunkowo stabilny w badanym okresie. Do pozostałych wydatków BHP zaliczono, między innymi, wydatki na: posiłki oraz napoje, profilaktyczne szkolenia oraz dodatki z tytułu szkodliwych warunków pracy. Stanowiły one od 5,2\% (2012 r.) do 5,8\% (2010 r.) ogółu analizowanych wydatków.

Względne wydatki na szkolenia BHP pracowników wykazały w badanym okresie tendencję wzrostu (z 2,8\% w 2008 r. do 4,1\% w 2012 r.). Udział pozostałych kategorii wydatków, takich jak: utrzymanie szatni pracowniczej, pomiar czynników szkodliwych dla zdrowia na stanowiskach pracy, zakup i instalacja środków ochrony zbiorowej pracowników, nie przekraczał $2 \%$.

W dalszym etapie badań dokonano oceny struktur wydatków działalności prewencyjnej w zakresie BHP w zależności od badanej branży. Z badań tych wynika, że struktury te są zróżnicowane.

W branży przetwarzanie i konserwowanie mięsa oraz produkcja wyrobów z mięsa wyróżniają się wydatki poniesione na zakup odzieży i obuwia roboczego, stanowiąc średnio ponad 30\% ogólnych wydatków BHP (tab. 3). Wydatki na zakup środków czystości wynosiły ponad 25\%, a na zakup środków ochrony indywidualnej pracowników około 20\% ogólnej sumy wydatków BHP poniesionych przez badane przedsiębiorstwa tejże branży. 
Tabela 3

Struktura wydatków na działalność prewencyjną w zakresie BHP w badanych przedsiębiorstwach branży przetwarzanie i konserwowanie mięsa oraz produkcja wyrobów z mięsa, w województwie łódzkim w latach 2008-2012 [\%]

\begin{tabular}{|c|c|c|c|c|c|c|c|c|c|c|}
\hline $\begin{array}{l}\text { v } \\
\text { Q }\end{array}$ & 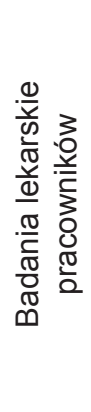 & 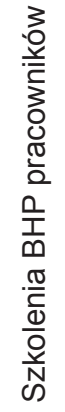 & 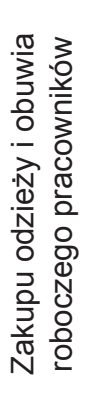 & 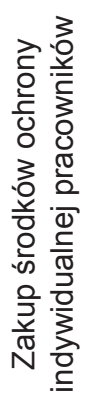 & 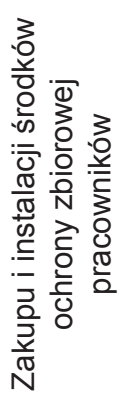 & 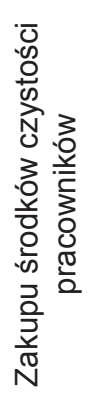 & 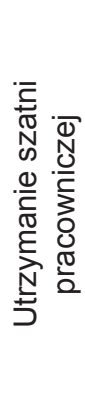 & 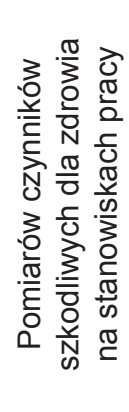 & 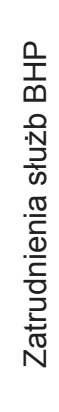 & $\begin{array}{l}\frac{D}{D} \\
\frac{\pi}{N} \\
D \\
0 \\
0\end{array}$ \\
\hline 2008 & 4,4 & 1,8 & 30,7 & 20,0 & 0,0 & 27,6 & 1,9 & 0,6 & 8,4 & 4,6 \\
\hline 2009 & 4,7 & 2,2 & 30,3 & 19,7 & 0,8 & 25,0 & 3,2 & 0,8 & 8,9 & 4,6 \\
\hline 2010 & 4,4 & 2,1 & 32,3 & 19,0 & 0,1 & 25,3 & 1,8 & 1,1 & 9,2 & 4,8 \\
\hline 2011 & 4,7 & 2,3 & 33,4 & 18,2 & 0,0 & 24,7 & 1,8 & 0,8 & 8,9 & 5,3 \\
\hline 2012 & 4,7 & 2,0 & 32,5 & 17,9 & 0,0 & 25,5 & 1,8 & 0,9 & 9,6 & 5,1 \\
\hline
\end{tabular}

Źródło: Badanie własne.

\section{Tabela 4}

Struktura wydatków na działalność prewencyjna w zakresie BHP w badanej branży produkcji wyrobów piekarskich i mącznych, w województwie łódzkim w latach 2008-2012 [\%]

\begin{tabular}{|c|c|c|c|c|c|c|c|c|c|c|}
\hline 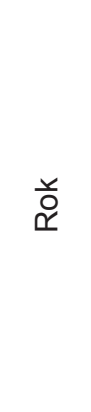 & 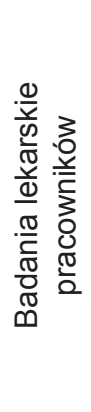 & 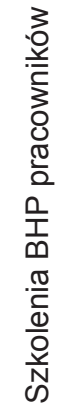 & 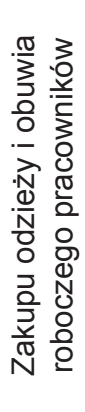 & 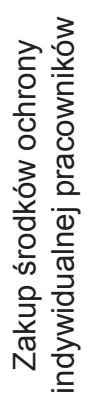 & 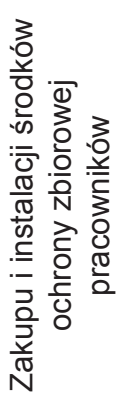 & 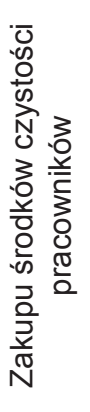 & 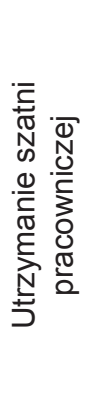 & 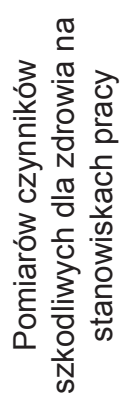 & 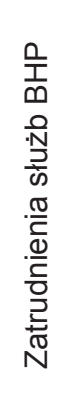 & $\begin{array}{l}0 \\
\frac{D}{\pi} \\
\text { N } \\
\text { N } \\
0 \\
0\end{array}$ \\
\hline 2008 & 53,5 & 4,8 & 11,8 & 6,0 & 1,0 & 11,5 & 2,4 & 1,8 & 4,3 & 2,8 \\
\hline 2009 & 12,2 & 11,5 & 20,2 & 10,3 & 2,5 & 22,4 & 4,4 & 2,9 & 7,7 & 5,9 \\
\hline 2010 & 12,4 & 8,3 & 21,8 & 9,5 & 4,0 & 22,0 & 4,6 & 3,2 & 8,0 & 6,1 \\
\hline 2011 & 12,3 & 9,2 & 18,1 & 10,3 & 5,4 & 21,8 & 5,4 & 3,8 & 8,0 & 5,6 \\
\hline 2012 & 12,4 & 10,8 & 21,1 & 9,6 & 2,5 & 23,8 & 3,6 & 3,3 & 8,0 & 4,8 \\
\hline
\end{tabular}

Źródło: Badanie własne. 
W branży określonej produkcją wyrobów piekarskich i mącznych (tab. 4) największy udział miały wydatki na zakup środków czystości dla pracowników oraz odzieży i obuwia roboczego, a także badania lekarskie. Należy uznać to za zjawisko niekorzystne.

$\mathrm{Z}$ danych zawartych w tabeli 5 wynika, że w branży zajmującej się wytwarzaniem wyrobów mleczarskich, w grupie wydatków BHP dominowały te powiązane z zakupem odzieży i obuwia roboczego pracowników (28-36\% ogółu wydatków BHP), badaniami lekarskimi (19-23\%), wydatki na zatrudnienie służb BHP (13-15\%) oraz wydatki pozostałe (9-15\%).

\section{Tabela 5}

Struktura wydatków na działalność prewencyjną w zakresie BHP w badanych przedsiębiorstwach branży wytwarzanie wyrobów mleczarskich, w województwie łódzkim w latach 2008-2012 [\%]

\begin{tabular}{|c|c|c|c|c|c|c|c|c|c|c|}
\hline $\begin{array}{l}\text { 하 } \\
\text { प }\end{array}$ & 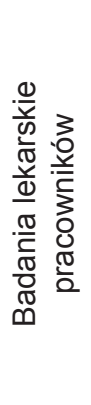 & 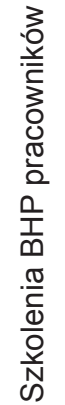 & 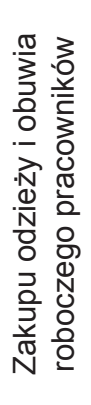 & 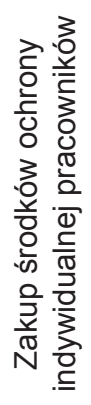 & 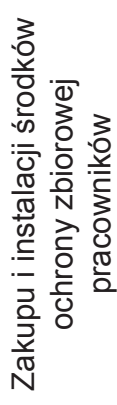 & 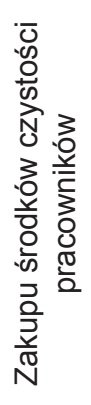 & 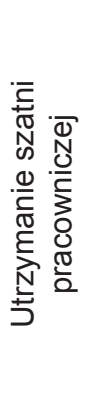 & 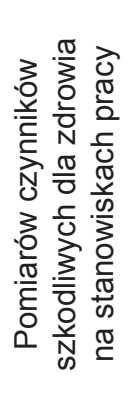 & 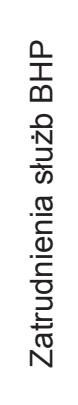 & $\begin{array}{l}0 \\
\frac{\pi}{W} \\
\text { N } \\
N \\
0 \\
0\end{array}$ \\
\hline 2008 & 22,4 & 3,5 & 28,0 & 8,5 & 0,8 & 5,8 & 0,1 & 1,4 & 14,6 & 15,1 \\
\hline 2009 & 22,9 & 5,6 & 28,1 & 9,2 & 0,5 & 4,0 & 0,1 & 1,7 & 15,0 & 12,9 \\
\hline 2010 & 20,4 & 4,0 & 31,9 & 10,9 & 1,0 & 5,2 & 0,1 & 0,6 & 14,0 & 12,1 \\
\hline 2011 & 20,8 & 4,5 & 33,1 & 7,4 & 5,4 & 5,2 & 0,1 & 0,9 & 12,7 & 9,8 \\
\hline 2012 & 18,9 & 6,4 & 36,2 & 8,9 & 0,9 & 2,9 & 0,1 & 2,9 & 13,3 & 9,5 \\
\hline
\end{tabular}

Źródło: Badanie własne.

W branży przetwarzanie i konserwowanie owoców i warzyw (tab. 6), wśród wydatków BHP w poszczególnych latach największy odsetek stanowiły kolejno wydatki na: zakup odzieży i obuwia ochronnego pracowników (25$-27 \%$ ), zakup środków czystości pracowników (22-26\%) oraz badania lekarskie $(12-15 \%)$.

W branży produkującej napoje (tab. 7) największy udział miały wydatki zrealizowane na zakup odzieży i obuwia roboczego pracowników (48-54\% ogółu wydatków BHP). Udział wydatków na zatrudnienie służby BHP zwiększył się z prawie $22 \%$ w 2008 roku do ponad 27\% w 2012 roku, podczas gdy udział wy- 
Tabela 6

Struktura wydatków na działalność prewencyjną w zakresie BHP w przedsiębiorstwach branży przetwarzanie i konserwowanie owoców i warzyw, w województwie łódzkim w latach 2008-2012 [\%]

\begin{tabular}{|c|c|c|c|c|c|c|c|c|c|c|}
\hline \begin{tabular}{l} 
하 \\
\} & 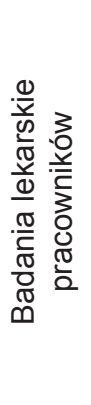 & 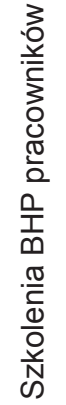 & 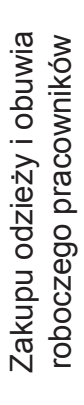 & 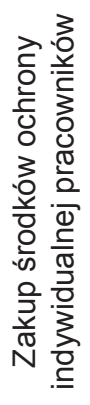 & 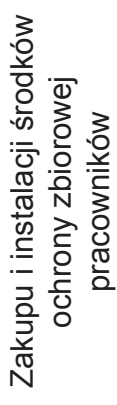 & 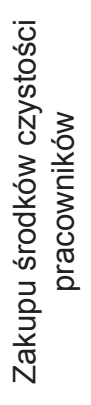 & 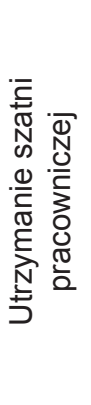 & 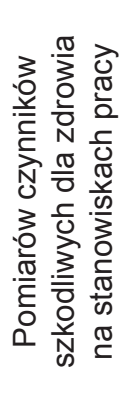 & 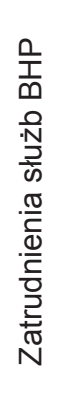 & $\begin{array}{l}\frac{0}{N} \\
\frac{\pi}{N} \\
0 \\
0 \\
0\end{array}$ \\
\hline 2008 & 13,8 & 3,6 & 26,0 & 7,8 & 7,3 & 25,7 & 5,1 & 1,9 & 8,0 & 0,9 \\
\hline 2009 & 13,3 & 3,6 & 27,3 & 7,6 & 7,8 & 26,4 & 4,6 & 1,1 & 7,5 & 0,9 \\
\hline 2010 & 11,8 & 3,7 & 25,8 & 7,5 & 10,6 & 26,7 & 3,7 & 1,6 & 7,7 & 1,0 \\
\hline 2011 & 15,5 & 4,2 & 25,5 & 8,5 & 7,5 & 21,9 & 5,4 & 2,2 & 8,8 & 0,6 \\
\hline 2012 & 13,5 & 3,9 & 25,4 & 7,5 & 9,3 & 23,7 & 5,3 & 1,7 & 9,2 & 0,4 \\
\hline
\end{tabular}
\end{tabular}

Źródło: Badanie własne.

Tabela 7

Struktura wydatków na działalność prewencyjną w zakresie BHP w przedsiębiorstwach branży produkcji napojów, w województwie łódzkim w latach 2008-2012 [\%]

\begin{tabular}{|c|c|c|c|c|c|c|c|c|c|}
\hline $\begin{array}{l}\text { 하 } \\
\stackrel{\Upsilon}{ }\end{array}$ & 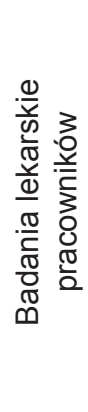 & 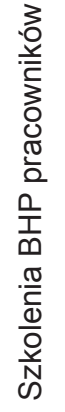 & 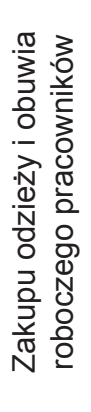 & 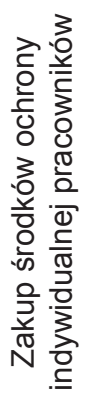 & 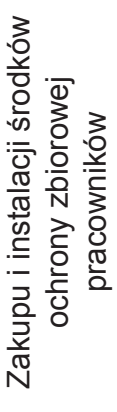 & 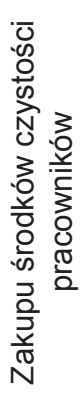 & 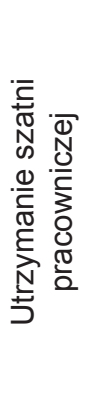 & 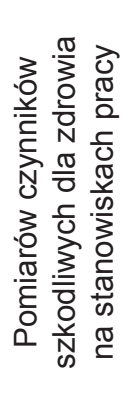 & 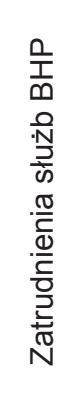 \\
\hline 2008 & 18,0 & 2,2 & 53,7 & 0,0 & 0,0 & 4,3 & 0,0 & 0,0 & 21,8 \\
\hline 2009 & 16,8 & 1,1 & 53,5 & 0,0 & 0,0 & 4,4 & 0,0 & 0,0 & 24,1 \\
\hline 2010 & 18,5 & 2,2 & 51,4 & 0,0 & 0,0 & 3,3 & 0,0 & 0,0 & 24,6 \\
\hline 2011 & 17,2 & 1,0 & 50,8 & 0,0 & 0,0 & 6,4 & 0,0 & 0,0 & 24,7 \\
\hline 2012 & 14,9 & 0,9 & 48,1 & 0,0 & 0,0 & 8,7 & 0,0 & 0,0 & 27,5 \\
\hline
\end{tabular}

Źródło: Badanie własne. 
datków na badania lekarskie pracowników odpowiednio zmniejszył się z 18\% do prawie $15 \%$ w badanym okresie.

Dane zawarte w tabeli 8 wskazują, że przy produkcji pozostałych artykułów spożywczych (kakao, czekolady, kawy, ryb itd.) największe, w stosunku do ogółu wydatków na BHP, były wydatki związane z nabyciem odzieży i obuwia roboczego pracowników, przy czym nastąpił spadek ich udziału (z 41\% w $2008 \mathrm{r}$. do $37 \%$ w 2012 r.). Ponadto w branży tej znaczne było obciążenie wydatkami na zatrudnianie służb BHP (ok. 25\%) oraz na badania lekarskie pracowników (12-18\% ogółu wydatków na BHP).

\section{Tabela 8}

Struktura wydatków na działalność prewencyjną w zakresie BHP w branży produkującej pozostałe artykuły spożywcze (kakao, czekolady, kawy, ryb itd.), w województwie łódzkim w latach 2008-2012 [\%]

\begin{tabular}{|c|c|c|c|c|c|c|c|c|c|c|}
\hline \begin{tabular}{l} 
वे \\
\} & 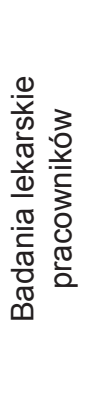 & 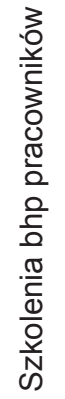 & 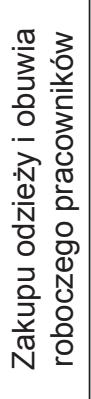 & 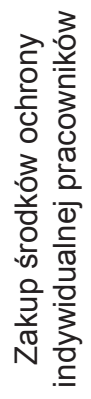 & 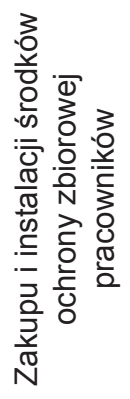 & 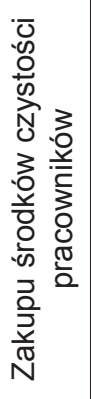 & 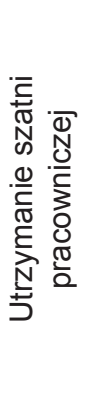 & 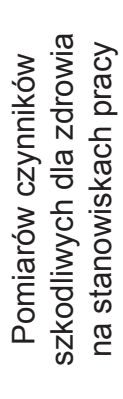 & 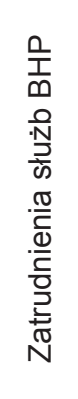 & $\begin{array}{l}\frac{0}{0} \\
\frac{\pi}{\omega} \\
\text { N } \\
0 \\
0\end{array}$ \\
\hline 2008 & 11,8 & 3,5 & 40,8 & 5,7 & 0,0 & 9,6 & 0,6 & 2,5 & 25,5 & 0,0 \\
\hline 2009 & 11,7 & 6,2 & 43,3 & 5,5 & 0,0 & 7,7 & 0,6 & 1,2 & 24,0 & 0,0 \\
\hline 2010 & 15,9 & 3,3 & 40,3 & 5,4 & 0,0 & 9,1 & 0,6 & 1,8 & 23,7 & 0,0 \\
\hline 2011 & 16,7 & 2,0 & 41,8 & 5,7 & 0,0 & 9,4 & 0,6 & 1,0 & 22,9 & 0,0 \\
\hline 2012 & 17,9 & 6,0 & 37,1 & 5,9 & 0,0 & 6,6 & 0,7 & 0,9 & 24,9 & 0,0 \\
\hline
\end{tabular}
\end{tabular}

Źródło: Badanie własne.

\section{Podsumowanie i wnioski}

Przeprowadzone badania dotyczyły dużych przedsiębiorstw sektora przemysłu spożywczego w województwie łódzkim w latach 2008-2012, funkcjonujących $\mathrm{w}$ ramach sześciu różnych branż. Uzyskane wyniki nie mogą być więc uogólniane na całą populację przedsiębiorstw sektora przemysłu spożywczego w Polsce. Mogą one jednak stanowić źródło informacji dla ekonomistów gospodarki żywnościowej oraz osób kierujących sprawami BHP.

W wyniku przeprowadzonych badań własnych sformułowano następujące wnioski: 
1. Mimo iż w latach 2008-2012 w badanych podmiotach nastapiło znaczne zwiększenie się (o 29\%) liczby wypadków przy pracy, poniesione przez nie $\mathrm{w}$ tym okresie wydatki związane $\mathrm{z}$ bezpieczeństwem i higieną pracy zwiększyły się zaledwie o $2,5 \%$.

2. Największy (ok. 30-procentowy) udział w całkowitych wydatkach na BHP w badanych przedsiębiorstwach zajmowały wydatki na zakup odzieży i obuwia roboczego pracowników.

3. Biorąc pod uwagę zmiany poziomu i struktury wydatków powiązanych z zapewnieniem bezpieczeństwa i higieny pracy przez badane przedsiębiorstwa, ich działalność w tym zakresie należy ocenić negatywnie, gdyż sprowadzała się ona zazwyczaj do zapewniania pracownikom jedynie niezbędnych środków pozwalających na wykonywanie powierzonych im czynności.

4. Poza tym, że wydatki na BHP były zbyt małe i nie przynosiły oczekiwanych efektów, ich zwiększenie się nie miało charakteru wyprzedzającego względem zmian skali wypadków przy pracy. Pożądane są zatem zmiany organizacyjne i ekonomiczne $\mathrm{w}$ badanych przedsiębiorstwach, które umożliwiłyby wyprzedzające - w stosunku do zdarzeń wypadkowych - zwiększanie wydatków na BHP. Długofalowe, wyprzedzające ponoszenie wydatków na działalność profilaktyczną BHP powinno przynosić wymierne korzyści dla przedsiębiorstw.

\section{Literatura}

JAKUBOWSKA M., 1978: Społeczno-ekonomiczne zachęty do poprawy stanu bhp, IWCRZZ, Warszawa.

KLEPACKI B., 1984: Wybór próby w badaniach ekonomiczno-rolniczych, Wydaw. SGGW-AR, Warszawa.

LANGE O., 1990: Ekonomia - przedmiot, zakres i metody, tom 2, [w:] Wybór pism, PWN, Warszawa.

MACIOŁEK H., ZIELIŃSKA A., 2012: Aspekty bezpieczeństwa i higieny pracy $w$ produkcji rolno-hodowlanej $w$ świetle wybranych regulacji prawnych, Journal of Ecology and Health 16(4), 173-186.

MANTEUFFEL R., 1979: Ekonomika i organizacja gospodarstwa rolniczego, PWRiL, Warszawa.

PAWŁOWSKA Z., RZEPECKI J., 1998: Metody obliczania kosztów wypadków przy pracy w przedsiębiorstwie, Bezpieczeństwo Pracy 5, 34-37.

RZEPECKI J., SERAFIŃSKA A., 2004: Koszty wypadków przy pracy w Polsce, Prewencja i Rehabilitacja 5(3), 1-4.

SIARNECKI K., 2001: Ile kosztuja wypadki, Przyjaciel przy Pracy, 10-13.

URBAN R., 2010: Przemyst spożywczy w procesie integrowania z Uniq Europejska, Przyspieszenie rozwoju polskiego przemystu spożywczego [w:] R. Urban, I. Szczepaniak, R. Mroczek (red.), Polski sektor żywnościowy w pierwszych latach członkostwa (Synteza), ERiGŻ-PIB, Warszawa, 22-35.

ZUS, 2009: Prewencja wypadkowa prowadzona przez Zakład Ubezpieczeń Społecznych, Warszawa. 


\begin{abstract}
Abstrakt
Artykuł przedstawia poziom i strukturę wydatków ponoszonych przez przedsiębiorstwa na profilaktykę związaną z BHP. Badaniem zostały objęte duże przedsiębiorstwa przemysłu spożywczego na terenie województwa łódzkiego. Jak wynika z przeprowadzonych badań, w latach 2008-2012 liczba wypadków przy pracy wzrosła o $29 \%$, podczas gdy koszty profilaktyki BHP zwiększyły się zaledwie o 2,5\%. Należy ocenić to negatywnie, gdyż działalność w zakresie bezpieczeństwa i higieny pracy nie powinna sprowadzać się do zapewniania pracownikom wyłącznie podstawowych środków pozwalających na wykonywanie powierzonych im czynności. Wydatki na BHP były zbyt niskie i nie przyniosły oczekiwanych efektów. Ponadto, ich zwiększenia się nie miało charakteru wyprzedzającego względem zmian skali wypadków przy pracy.
\end{abstract}

Słowa kluczowe: sektor, przemysł spożywczy, wydatki, wypadki przy pracy, prewencja

\title{
The comparative analysis of the level and structure of expenditures on occupational safety and health in the food industry companies in the Kodz region
}

\begin{abstract}
The article describes the level and structure of company's expenditures attributed to the prevention of the occupational safety and health risks. The survey was conducted on food companies in the Lodz region. The research reveals that over the period of 2008-2012 the number of work accidents increased by about $29 \%$ while the prevention-related spending increased by merely $2.5 \%$. This situation must be negatively assessed because the company's activity in the area of occupational safety and health at a workplace should not be reduced to providing workers with basic resources enabling them to conduct the entrusted activities. The expenditures on prevention programs were too low and ineffective. Moreover, the increase of the occupational safety and health spending did not have any impact on the changes in the number of accidents at a workplace.
\end{abstract}

Key words: sector, food industry, expenses, work accidents, prevention 